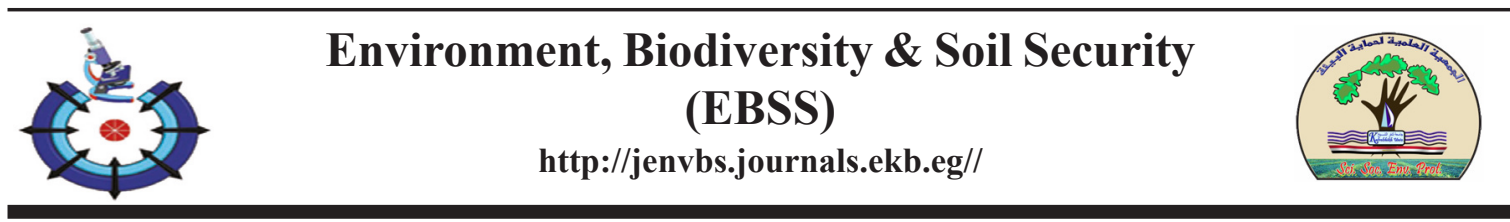

\title{
Quality Assessment of Some Water Sources and Soil under Sea Water Intrusion Conditions in North Nile Delta, Egypt
}

\author{
Mohamed El-Ghannam*, Mona K. Abdel-Razek and Hesham Aboelsoud \\ Soils, Water and Environment Research Institute, Agricultural Research Center, Giza, \\ Egypt.
}

\begin{abstract}
$\mathbf{P}$ OOR water quality mainly exists because of the increasing population and horizontal expansion which are associated with deterioration in sanitation and crop productivity. The present study is aiming to assess the quality of different water sources and soil under sea water intrusion along 3 directions in North Delta, Kafr El-Sheikh Governorate. A total of 45 water samples were collected from 15 locations along 3 lines. The results showed that the salinity, sodicity and nitrate concentrations of irrrigarion water were increased toward the north due to the use of blended water for irrigation. The concentrations of $\mathrm{Mn}, \mathrm{Pb}, \mathrm{Cd}, \mathrm{Fe}$ and $\mathrm{Zn}$ for all drains were varied from 0.20 to $1.36,0.15$ to $0.97,0.0$ to $0.2,0.29$ to 2.70 and 0.0 to 0.1 $\mathrm{mgL}^{-1}$, respectively. The lowest values of soil salinity and sodicity were recorded far from the sea, while the highest values were recorded near the sea. It could be rendered to the effect of artesian pressure of saline ground water near the sea, where the highest value reached $20.25 \mathrm{dS}$ $\mathrm{m}^{-1}$ in line 1 and the lowest value was observed in line 3 . Sea water intrusion were calculated for the studied ground water samples and followed the decending order of : line $3>$ line $2>$ line 1 . On the other hand, appreciable quantities of residual sodium carbonate (RSC) were -1.51,-7.99 and -34.1 for irrigation, drainage and groundwater, respectively. The water samples having high RSC can have an appreciable sodicity hazard.
\end{abstract}

Keywords: Salinity, Sodicity, Nitrate, Heavy metals, Sea water intrusion.

\section{Introduction}

Lakes and reservoirs are major water resources as these hold about $90 \%$ of the world's surface fresh water and are the key for agriculture (Afify et al. 2019). Water resources in Egypt are limited to the withdrawal share from the Nile water; the limited quantity of rainfall and groundwater. The non-traditional resources of water include reuse of treated wastewater and agricultural drainage water, as well as the desalinization of seawater and brackish water (Allam and Allam 2007).

The rapid increase in population growth will threaten a severe shortage of drinking water supplies in the nearest future and rapid deterioration is occurring in surface and groundwater quality (Shepl et al. 2017).

The Nile River sediments are the major source of persistent bioaccumulative toxic chemicals which may threaten the ecological and human health, even after contaminants are no longer released from sources (Eaton et al. 2013). Nowadays, water pollution is a serious problem in the majority of developing countries. It is usually caused by untreated sewage, industrial discharges, and agricultural chemicals. During the next decades, problems will associate with lack of water and pollution of water, In addition, without adequate quality and sufficient quantities of water, billions of people will continue to suffer illness arising from a poor environment, improper disposal of excreta and polluted water (Awad 2019).

Environmental pollution caused by toxic heavy metals constitutes a significant problem in our modern society and particularly water pollution due to the disposal of heavy metals is a

*Corresponding author e-mail: khattab.ph7@gmail.com

Received 3/11/2019; Accepted 28/11/2019

DOI: 10.21608/JENVBS.2019.19036.1073

C2019 National Information and Documentation Center (NIDOC) 
great concern worldwide (Petros et al. 2019). The physical and chemical approaches can be used to evaluate the water quality in relevant locations. Further studies based on biological approaches should be also carried out. (Abdallah et al. 2019). It can be demonstrated that expansions of groundwater pollution is more along Industrial area as compared to agricultural and residential zones (Anwar and Abdul Gaffar 2018).

The deterimental consequences of nitrate leaching affecting groundwater quality are much more evident in intensive agricultural areas and, particularly, in arid and semi-arid regions. In such areas, the use of saline water is a further likely option to meet crop water requirements (Ibrikci et al. 2015). Nitrate nitrogen concentrations leaving surface drains in North Delta, Egypt exceed the U.S. Environmental Protection Agency (1991) maximum contaminant level for drinking water of $10 \mathrm{mg} \mathrm{L}^{-1}$. There is an urgent need to monitor and assess soil quality especially in salt-affected soils because these soils can be used to increase food and feed productivity; enhance environmental quality and increase carbon sequestration (Elbasiouny 2017). Injudicious use of poor quality ground waters in many arid and semi-arid regions for irrigation leads to the build-up of salinity and/or sodicity in soil and deterioration of soil health because of which sustainability of crop production is adversely affected (Choudhary and Kharche 2018).

To achieve the proper management of groundwater resource in this region, it is important to understand the patterns of seawater movement and mixing between fresh and saline groundwater In order to understand the salinity distribution and seawater movement, the actual heterogeneity and stratigraphy of the Nile Delta aquifer should be determined. (El-Kiki 2018). Therefore, the aim of the present study is to investigate, salinity and some agrochemical pollutants (nitrate and heavy metals) in surface and groundwater and soil in North Nile Delta.

\section{Materials and Methods}

Fiveteen locations in Northern Part of the Nile delta in Kafr El-Shiekh Governorate, between $31^{\circ} 10^{\prime} 22^{\prime \prime}$ and $31^{\circ} 16^{\prime} 10^{\prime \prime} \mathrm{N}$ latitude and $30^{\circ} 35^{\prime}$ $25^{\prime \prime}$ and $30^{\circ} 39^{\prime}$ 36" E longitude, starting from Kafr El-Shiekh towards the Mediterranean Sea, in three directions where the length of line about $30 \mathrm{~km}$ and the distance between the lines a bout $10 \mathrm{~km}$ (Fig. 1). Some chemical properties of irrigation, drainage, groundwater as well as the soil were measured. All studied locations are clayey in texture where the clay content was more than $50 \%$. The water samples were collected starting from December, 2017 to August, 2018. Sample of 2.5 liter was collected three times from each location for drains and canals at $50 \mathrm{~cm}$ depth below the water surface and stored in clean Pyrex borosilicate brown glass bottles for chemical analysis.

\section{Water analysis}

Water samples were filtrated using filter paper No.1 and subjected to chemical analysis as follows: $\mathrm{EC}, \mathrm{pH}$ and soluble cations and anions were determined as described by (Rowell 1994). Also, SAR parameter was calculated using Richard equation (1954).

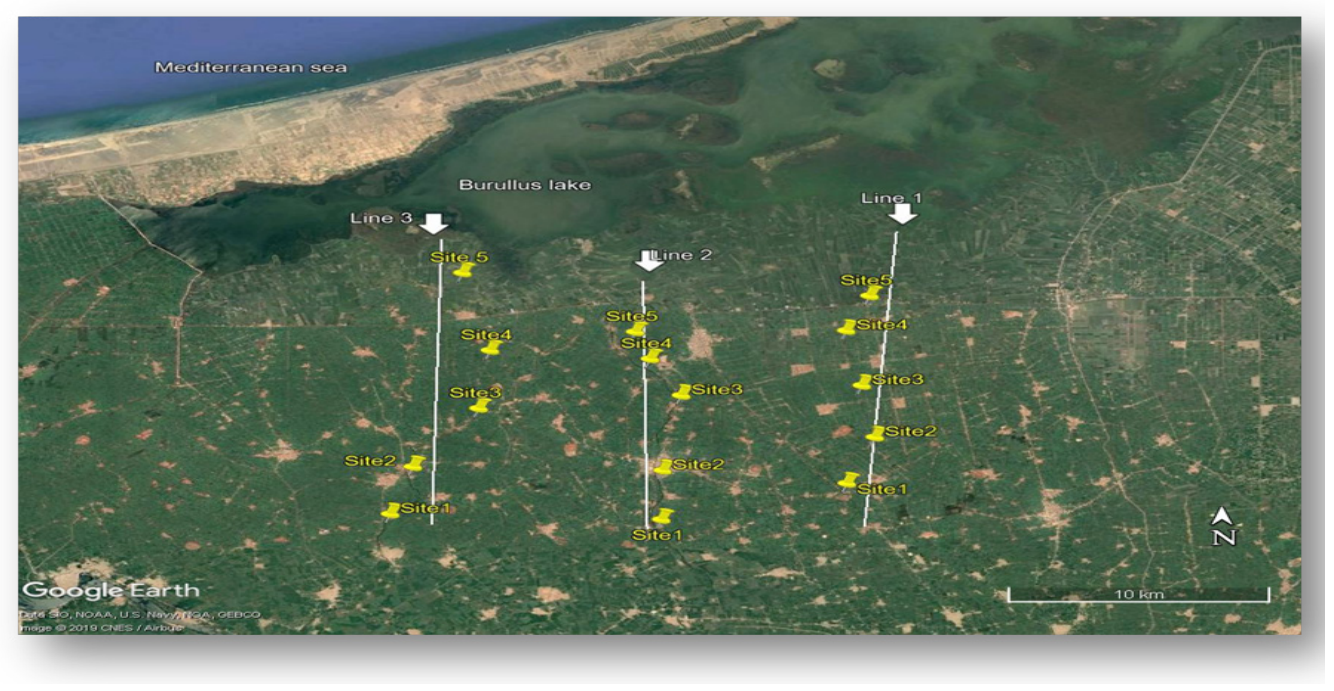

Fig. 1. Locations of the studied area. 
Soluble heavy metals (Mn, $\mathrm{Zn}, \mathrm{Cd}, \mathrm{Fe}$ and $\mathrm{Pb}$ ) were determined using the standard method described by using Atomic Adsorption Spectrophotometer Perkin Elmer 3300. And nitrate in water samples were analyzed using Kjeldahl method (Cottenie et al. 1982).

\section{Soil analysis}

Sampling sites were selected to represent the major soil analysis in the study area. Soil surface samples $(0-30 \mathrm{~cm})$ were collected at approximately $20-30 \mathrm{~m}$ far from drains. The samples were sealed in polyethylene bags and transported to the laboratory for analysis. The collected soil samples were air dried at room temperature $\left(25^{\circ} \mathrm{C}\right)$, pulverized, Passed through $2 \mathrm{~mm}$ sieve and stored to be ready for further analysis. The characteristics of soil samples were measured as follow:

Soil $\mathrm{pH}$ was measured at 1:2.5 (soil: deionized water suspension) using a calibrated $\mathrm{pH}$-meter (Jenway 3510, UK). Soil salinity was measured in supernatant of 1:5 soil: water extract using ECmeter (Rowell 1994)

Available potential toxic elements: Ten grams of air-dried soil was placed in a $125-\mathrm{ml}$ conical flask, and $20 \mathrm{ml}$ of the DTPA extracting solution was added. Each flask was covered with stretchable Parafilm and secured upright on a horizontal shaker with a stroke of $8.0 \mathrm{~cm}$ with a speed of 120 cycles/min. After 2 hours shaking, the suspensions were filtered by gravity through Whatman no. 42 filter paper. The filtrates were analyzed for $\mathrm{Zn}, \mathrm{Fe}, \mathrm{Mn}, \mathrm{Cd}$ and $\mathrm{Pb}$ using atomic absorption spectrophotometry and appropriate standards perkinelmer 3300) (Lindsay and Norvell, 1978).

Available nitrogen was extracted by $2 \mathrm{M} \mathrm{KCl}$. According to cottenie et al. (1982), using a semiAutomatic-micro Kjeldahl (Behr2).

Calculated the sea water intrusion with groundwater

$>$ Based on the range of $\mathrm{Cl}^{-1} / \mathrm{CO}_{3}^{-2}$ $+\mathrm{HCO}_{3}^{-}$) ratio and the water can be classified as follow:

a) fresh ground water $(<0.05)$,

b) slightly contaminated ground water (0.051.30),

c) moderately contaminated ground water (1.3 $-2.8)$,

d) injuriously contaminated ground water (2.86.6),

e) highly contaminated ground water (near sea water) (6.6-15.5) f) sea water (>20.0) (Mohan Babu et al., 2013)

Quality indices

$>$ Water quality classes according to USDA (1954) were; C1, C2, C3 and C4, represent low, medium, high and very high salinity and also, $\mathrm{S} 1, \mathrm{~S} 2, \mathrm{~S} 3$ and S4 represent low, medium, high and very high sodicity, respectively.

SCAR; Sodium: Calcium activity ratio=

$\mathrm{Na} 2 \div \sqrt{\mathrm{Ca}}$ meq/1

$>\mathrm{RSC}=\left(\mathrm{CO}_{3}^{2-}+\mathrm{HCO}^{3-}\right)-\left(\mathrm{Ca}^{2+}+\mathrm{Mg}^{2+}\right)$

$>$ Salinity was measured in terms of electric conductivity EC measured as $\mathrm{dSm}^{-1}$. Soluble sodium percentage (SSP) was calculated according the following:

$$
\begin{gathered}
S S P=\frac{N a}{\sum \text { Cations }} * 100 \\
>\quad \text { Magnesium Hazards } \\
M H=M g+(C a+M g)
\end{gathered}
$$

The permeability index PI was calculated according to (Doneen, 1964).

$$
P I=\frac{N a+\sqrt{H C O 3}}{N a+C a+M g} \times 10
$$

The other measurements were made by Irrigation Water Assessment Model (IWA-Mod), this model helps the users to evalute water quality. This model is a computer model that can be used to assess the quality of irrigation water through some important indicators such as salinity, SAR, SSP, RSC, SCAR, PS, MAR and PI)..... etc. IWA-Mod is an acronym for irrigation water assessment model.

The Geostatistical analyst in ArcGIS 10.1 (ESRI, 2012) was used to develop the semivariogram between each pair of points versus their separation distances. This semivariogram was used in predicting soil salinity within the studied area.

\section{$\underline{\text { Results and Discussion }}$}

- $\quad$ Salinity and sodicity in irrigation water

Data in Table (1) and Fig. (2) revealed that the salinity and sodicity values of the studied irrigation water samples ranged from 0.50 to $2.07 \mathrm{dS} / \mathrm{m}$ and 1.60 to 8.49 , respectively in all studied locations. Results showed that the salinity and sodicity of irrrigarion water were increased 
toward the north (end of canals). This may be due to the shortage of irrigation water in north parts and consequently irrigated by drainage water. The monitored concentrations of salinity and sodicity in the studied waterirrigation samples were mostly considered aslow to moderate according to international guideline concentrations of FAO (2002) which are ECw $<0.7-3 \mathrm{dS} \mathrm{m}^{-1}$ and SAR $<3-9 \%$. Generally, values of $\mathrm{pH}$ had narrow range in all water samples which varied from 7.01 to 7.44 . This water is considered suitable for irrigating almost all soils with little danger of the development of harmful levels of salinity and sodicity. It could be concluded that water quality in the line (El-Sheikh Ibrahimcanal and Shalama) was less than that in the Bahr El-Sedey (line) these results in agreement with (El-Ghannam 2012). The use of poor water quality for irrigation may play very bad role in the contamination and degradation of the agricultural soils. Generally, the long term application of the poor quality and polluted drainage water may increase the content of heavy metals.

\section{Nitratecon centration in irrigation water}

Nitrate concentrations of water samples collected from the studied irrigation canals (Table 1) varied from 3.55 to $27.55 \mathrm{mgL}^{-1}$. The majority of nitrate nitrogen concentrations leaving surface water in North Delta, Egypt exceed the U.S. Environmental Protection Agency (1991) may led to maximum contaminant level for drinking water of $10 \mathrm{mg} \mathrm{L}^{-1}$. Nitrate concentrations in irrrigarion water was increased toward the north (end of canals) due to the used of mixed water for irrigation. It is cleary shown from the data that NO3- values were increased towards Burullus lake may be due to increase the mobility of $\mathrm{NO}_{3}$ in soil solution and disposed to the drainage water (Antar et al. 2012).

\section{Heavy metals in irrigation water}

Heavy metals concentrations ( $\mathrm{Mn}, \mathrm{Pb}, \mathrm{Cd}, \mathrm{Fe}$ and $\mathrm{Zn}$ ) inirrigation water of North Delta (Table 1), varied from one metal to another and also from one canal to another. The concentrations of $\mathrm{Mn}, \mathrm{Pb}, \mathrm{Fe}$ and $\mathrm{Zn}$ for all irrigation canals were varied from 0.01 to $1.82,0.0$ to $0.20,0.0$ to 0.63 and 0.0 to $0.01 \mathrm{mgL}^{-1}$, respectively. Soil samples collected from different irrigation canals were free from $\mathrm{Cd}$. The obtained results were agreed with findings of Abd El-Razik (2019). The heavy metals of irrrigarion water were increased toward the north (end of canals) may due to the use of drainage water for irrigation.

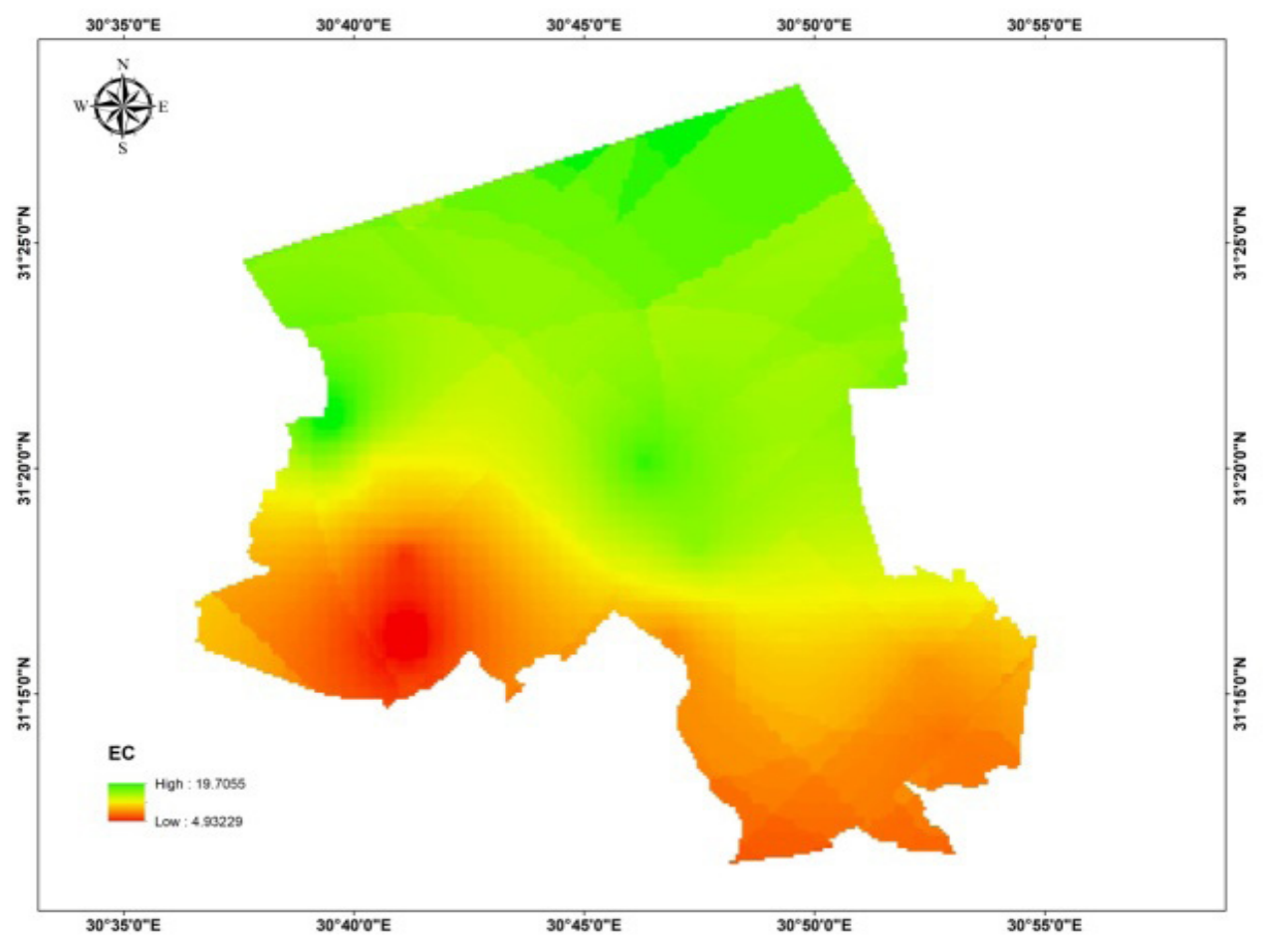

Fig. 2. The values of EC of irrigation water samples in the studied area. 
TABLE 1. The mean values of some irrigation water properties.

\begin{tabular}{|c|c|c|c|c|c|c|c|c|c|c|}
\hline & \multirow{2}{*}{ Site } & \multirow{2}{*}{$\begin{array}{c}\mathrm{EC} \\
\mathrm{dS} / \mathrm{m}\end{array}$} & \multirow{2}{*}{ SAR } & \multirow{2}{*}{ PH } & \multirow{2}{*}{$\begin{array}{l}\mathrm{NO}_{3}^{-} \\
\mathrm{mgl}^{-1}\end{array}$} & \multicolumn{5}{|c|}{ Available heavy metals $\left(\mathrm{mgl}^{-1}\right)$} \\
\hline & & & & & & Mn & $\mathbf{P b}$ & Cd & $\mathrm{Fe}$ & Zn \\
\hline \multirow{7}{*}{$\vec{\Xi}$} & L1 S1 & 0.55 & 2.49 & 7.22 & 9.35 & 0.03 & $\mathrm{Nd}$ & $\mathrm{Nd}$ & 0.05 & $\mathrm{Nd}$ \\
\hline & L1 S2 & 0.75 & 2.68 & 7.35 & 19.62 & 0.03 & 0.05 & $\mathrm{Nd}$ & 0.07 & $\mathrm{Nd}$ \\
\hline & L1 S3 & 0.8 & 3.33 & 7.32 & 23.15 & 0.04 & 0.06 & $\mathrm{Nd}$ & 0.09 & $\mathrm{Nd}$ \\
\hline & L1 S4 & 1.9 & 7.75 & 7.15 & 20.65 & 0.08 & 0.19 & $\mathrm{Nd}$ & 0.09 & $\mathrm{Nd}$ \\
\hline & L1S5 & 2.07 & 8.49 & 7.28 & 27.55 & 0.5 & 0.2 & $\mathrm{Nd}$ & 0.63 & $\mathrm{Nd}$ \\
\hline & Average & 1.2 & 4.9 & 7.3 & 20.1 & 0.1 & 0.1 & - & 0.2 & - \\
\hline & $\mathrm{SD}$ & 0.71 & 2.92 & 0.08 & 6.772 & 0.2 & 0.09 & - & 0.2 & - \\
\hline \multirow{7}{*}{$\stackrel{\sim}{\stackrel{\Xi}{\Xi}}$} & L2 S1 & 0.5 & 1.82 & 7.25 & 7.99 & 0.01 & 0.05 & $\mathrm{Nd}$ & 0.04 & $\mathrm{Nd}$ \\
\hline & L2 S2 & 0.55 & 1.60 & 7.39 & 11.82 & 0.02 & 0.05 & $\mathrm{Nd}$ & 0.05 & $\mathrm{Nd}$ \\
\hline & L2 S3 & 0.6 & 1.84 & 7.44 & 15.3 & 0.04 & 0.09 & $\mathrm{Nd}$ & 0.09 & $\mathrm{Nd}$ \\
\hline & L2 S4 & 0.85 & 2.14 & 7.25 & 18.86 & 1.66 & 0.13 & $\mathrm{Nd}$ & 0.25 & $\mathrm{Nd}$ \\
\hline & L2 S5 & 1.4 & 2.79 & 7.01 & 20.25 & 1.82 & 0.19 & $\mathrm{Nd}$ & 0.54 & 0.01 \\
\hline & Average & 0.78 & 2.0 & 7.3 & 14.8 & 0.7 & 0.1 & - & 0.2 & - \\
\hline & $\mathrm{SD}$ & 0.37 & 0.46 & 0.17 & 5.04 & 0.94 & 0.06 & - & 0.21 & 0.0 \\
\hline \multirow{7}{*}{$\stackrel{\overbrace{}}{\leftrightarrows}$} & L3 S1 & 0.9 & 2.62 & 7.2 & 3.55 & 0.01 & $\mathrm{Nd}$ & $\mathrm{Nd}$ & $\mathrm{Nd}$ & $\mathrm{Nd}$ \\
\hline & L3 S2 & 0.95 & 3.53 & 7.14 & 3.65 & 0.02 & $\mathrm{Nd}$ & $\mathrm{Nd}$ & $\mathrm{Nd}$ & $\mathrm{Nd}$ \\
\hline & L3 S3 & 1.1 & 3.42 & 7.02 & 9.5 & 0.04 & 0.05 & $\mathrm{Nd}$ & 0.05 & $\mathrm{Nd}$ \\
\hline & L3 S4 & 1.15 & 3.66 & 7.06 & 12.55 & 0.06 & 0.09 & $\mathrm{Nd}$ & 0.09 & 0.01 \\
\hline & L3 S5 & 1.45 & 3.57 & 7.2 & 17.45 & 0.18 & 0.13 & $\mathrm{Nd}$ & 0.25 & 0.01 \\
\hline & Average & 1.1 & 3.4 & 7.1 & 9.3 & 0.01 & 0.1 & - & 0.1 & 0.0 \\
\hline & SD & 0.22 & 0.42 & 0.08 & 5.96 & 0.07 & 0.06 & 0.0 & 0.1 & 0.0 \\
\hline
\end{tabular}

$\mathrm{Nd}$ : not detected, SD : standerd deviation.

- $\quad$ Salinity and sodicity of drainage water

The salinity and sodicity of the drainage water might be affected by some factors such as land use, crop pattern, soil management, drains locations and drainage system efficiency. Data in Table (2) revealed that salinity and sodicity values of the drainage water samples ranged from 1.40 to $4.45 \mathrm{dS} \mathrm{m}^{-1}$ and 2.06 to 10.62 , respectively. The monitored concentrations of salinity and sodicity in the studied drains water were mostly considered slight to moderate according to international guideline concentrations mentioned recommended by FAO/RNEA (1993). The increase in salinity and sodicity in the drainage water of this studied area, espcieally in the north are mainly ascribed to the inflow and contamination with the saline water through the soil and sea water intrusion. According to USDA diagram, the studied samples of all locations are in class $\mathrm{C}_{3} \mathrm{~S} 1$ and $\mathrm{C}_{4} \mathrm{~S}_{1}$. According to Richards (1954) classification $\mathrm{C}_{3} \mathrm{~S}_{1}$ and $\mathrm{C}_{4} \mathrm{~S}_{1}$ Class water are high to very high saline and low sodium content. Such water can be used with restricted drainage even with adequate drainage, special management for salinity control may be required, and salt tolerant crops must be selected. Therefore, such water is considered slightly dangerous for irrigation purposes. Values of $\mathrm{pH}$ had narrow range in all water samples which varied from 7.01 to 7.45 .

\section{Nitratein drainage water}

Nitrogen in drainage water is mainly in the form of nitrate, but may also be in the form of ammonium although ammonium that readily adsorbed by the colloids is rapidly oxidized into nitrates. Nitrate of water samples collected from the studied drains (Table 2) varied from 19.5 to $54.56 \mathrm{mgL}^{-1}$ in all drains. Nitrate nitrogen concentrations leaving surface drains in North Delta, exceed the maximum contaminant level for drinking water $\left(10 \mathrm{mg} \mathrm{L}^{-1}\right)$ according the U. S. Environmental Protection Agency (1991). The considerable variation in $\mathrm{NO}_{3}^{-}$concentration in drainage water may be ascribed to several factors including soil properties, amount of irrigation water, air temperature, evaporation rates, drainage system and forms of applied fertilizers, its uptake by plants and adsorption and fixation of $\mathrm{NH}_{4}^{+}$on the 2: 1 clay minerals (Dinnes et al. 2002).

\section{Heavy metals in drainage water}

With regard to heavy metals in drainage water, the data in Table (2) and Fig. (4) showed that the concentrations of $\mathrm{Mn}, \mathrm{Pb}, \mathrm{Cd}, \mathrm{Fe}$ and $\mathrm{Zn}$ for all drains were varied from 0.20 to $1.36,0.15$ to 0.97 , 
0.0 to $0.2,0.29$ to 2.70 and 0.0 to $0.1 \mathrm{mgL}^{-1}$, respectively. These results were agreed with findings of Abd El-Razik (2019).

The highest concentration levels for $\mathrm{Mn}$ and $\mathrm{Cd}$ in water drains were not permissible comparing to the maximum levels stated by FAO (1993) (0.2 and $0.01 \mathrm{mgL}^{-1}$, respectively). While, $\mathrm{pb}, \mathrm{Fe}$ and $\mathrm{Zn}$ concentrations ranged from 0.15 to 0.97 , 0.29 to 2.70 and 0.0 to $0.1 \mathrm{mgL}^{-1}$, respectively, they, therefore were lower than the maximum permissible levels stated by FAO (2002), (5, 5 and $2 \mathrm{mgL}^{-1}$, respectively). Therefore, the use of polluted drainage water without good treatment make these toxic elements accumulated in soil with time, leading to increase of their concentrations in soils and plants and therefore, enter into the food chain causing dangerous complications to man and other biota. These toxic metals may cause kidney and liver failure, anemia, cancer, in addition to chromosomal aberrations (El-Sanafawy et al. 2010).
- $\quad$ Soil salinity and sodicity

Salinity and sodicity values of the studied soil in Table (3) and Fig. (5) ranged from 0.85 to $8.73 \mathrm{dS} / \mathrm{m}$ and 2.68 to 12.11 , respectively. The lowest valuesof salinity and sodicity of the soil were recorded farfrom the sea and the northen lake, while the highest values were recorded near the sea and the northen lake. This may be due to the low quality of irrigation water and sea water intrusionin the northern area. $\mathrm{pH}$ values of the all soil samples (Table 3) were increased towards the sea and varied from 7.15 to 8.45 .

\section{Nitrogen in soil}

Nitrogen $(\mathrm{N})$ content of the studied soil samples (Table 3) varied from 22.6 to $190 \mathrm{mgL}^{-1}$. The majority of Ncontentin the studied soil exceed the critical level $40 \mathrm{mg} \mathrm{L}^{-1}$ according to U. S. Environmental Protection Agency (1991). The data showed that the $\mathrm{N}$ values were higher in the $1^{\text {st }}$ line than that in the $2^{\text {nd }}$ and $3^{\text {rd }}$ lines, may be due to the intensive application of mineral

TABLE 2.The mean values of some drainage water properties.

\begin{tabular}{|c|c|c|c|c|c|c|c|c|c|c|}
\hline & \multirow{2}{*}{ Site } & \multirow{2}{*}{$\mathrm{EC}, \mathrm{dS} / \mathrm{m}$} & \multirow{2}{*}{ SAR } & \multirow{2}{*}{ pH } & \multirow{2}{*}{$\begin{array}{l}\mathrm{NO}_{3} \\
\mathrm{mgl}^{-1}\end{array}$} & \multicolumn{5}{|c|}{ Available heavy metals $\left(\mathrm{mgl}^{-1}\right)$} \\
\hline & & & & & & Mn & $\mathbf{P b}$ & Cd & $\mathbf{F e}$ & Zn \\
\hline \multirow{7}{*}{ Ð } & L1 S1 & 1.4 & 2.06 & 7.18 & 19.5 & 0.2 & 0.15 & Nd & 0.45 & 0.01 \\
\hline & L1 S2 & 1.6 & 3.44 & 7.21 & 25.9 & 0.25 & 0.25 & Nd & 0.55 & Nd \\
\hline & L1 S3 & 1.85 & 3.27 & 7.24 & 35.8 & 0.26 & 0.35 & Nd & 0.65 & 0.01 \\
\hline & L1 S4 & 2.46 & 9.54 & 7.22 & 30.45 & 0.25 & 0.54 & Nd & 0.55 & 0.01 \\
\hline & L1 S5 & 3.79 & 8.45 & 7.01 & 29.5 & 0.55 & 0.25 & Nd & 0.7 & 0.01 \\
\hline & Average & 2.22 & 5.35 & 7.17 & 28.23 & 0.30 & 0.31 & - & 0.58 & 0.01 \\
\hline & SD & 0.90 & 0.39 & 0.09 & 6.03 & 0.14 & 0.15 & 0.0 & 0.1 & 0.0 \\
\hline \multirow{7}{*}{ ֶֶ, } & L2 S1 & 1.6 & 4.94 & 7.15 & 43.47 & 0.45 & 0.37 & Nd & 1 & 0.01 \\
\hline & L2 S2 & 2.0 & 3.95 & 7.19 & 41.45 & 0.75 & 0.85 & Nd & 1.15 & 0.02 \\
\hline & L2 S3 & 1.7 & 3.15 & 7.11 & 37.78 & 0.85 & 0.9 & Nd & 1.45 & 0.1 \\
\hline & L2 S4 & 2.2 & 3.78 & 7.25 & 25.75 & 0.5 & 0.72 & Nd & 2.6 & 0.01 \\
\hline & L2 S5 & 3.75 & 4.96 & 7.4 & 21.55 & 0.75 & 0.97 & Nd & 2.7 & 0.01 \\
\hline & Average & 2.25 & 4.16 & 7.22 & 34 & 0.66 & 0.76 & - & 1.78 & 0.03 \\
\hline & SD & 0.87 & 0.78 & 0.11 & 9.78 & 0.17 & 0.24 & 0.0 & 0.81 & 0.04 \\
\hline \multirow{7}{*}{$\stackrel{m}{\stackrel{m}{\Xi}}$} & L3 S1 & 1.5 & 7.55 & 7.45 & 52.45 & 0.9 & 0.6 & Nd & 1.5 & 0.1 \\
\hline & L3 S2 & 1.9 & 6.76 & 7.23 & 54.56 & 1.05 & 0.75 & Nd & 1.35 & 0.1 \\
\hline & L3 S3 & 2.2 & 10.52 & 7.29 & 30.45 & 1.5 & 0.65 & Nd & 1.55 & 0.01 \\
\hline & L3 S4 & 3.0 & 5.42 & 7.35 & 28.75 & 0.81 & 0.65 & 0.1 & 0.35 & 0.05 \\
\hline & S3 S5 & 4.45 & 5.48 & 7.44 & 25.75 & 1.36 & 0.25 & 0.2 & 0.29 & 0.02 \\
\hline & Average & 2.6 & 7.15 & 7.35 & 38.39 & 1.12 & 0.58 & 0.15 & 1.01 & 0.06 \\
\hline & SD & 0.96 & 3.39 & 0.09 & 6.03 & 0.14 & 0.15 & 0.0 & 0.10 & 0.0 \\
\hline
\end{tabular}

Nd : not detected, SD : standerd deviation. 

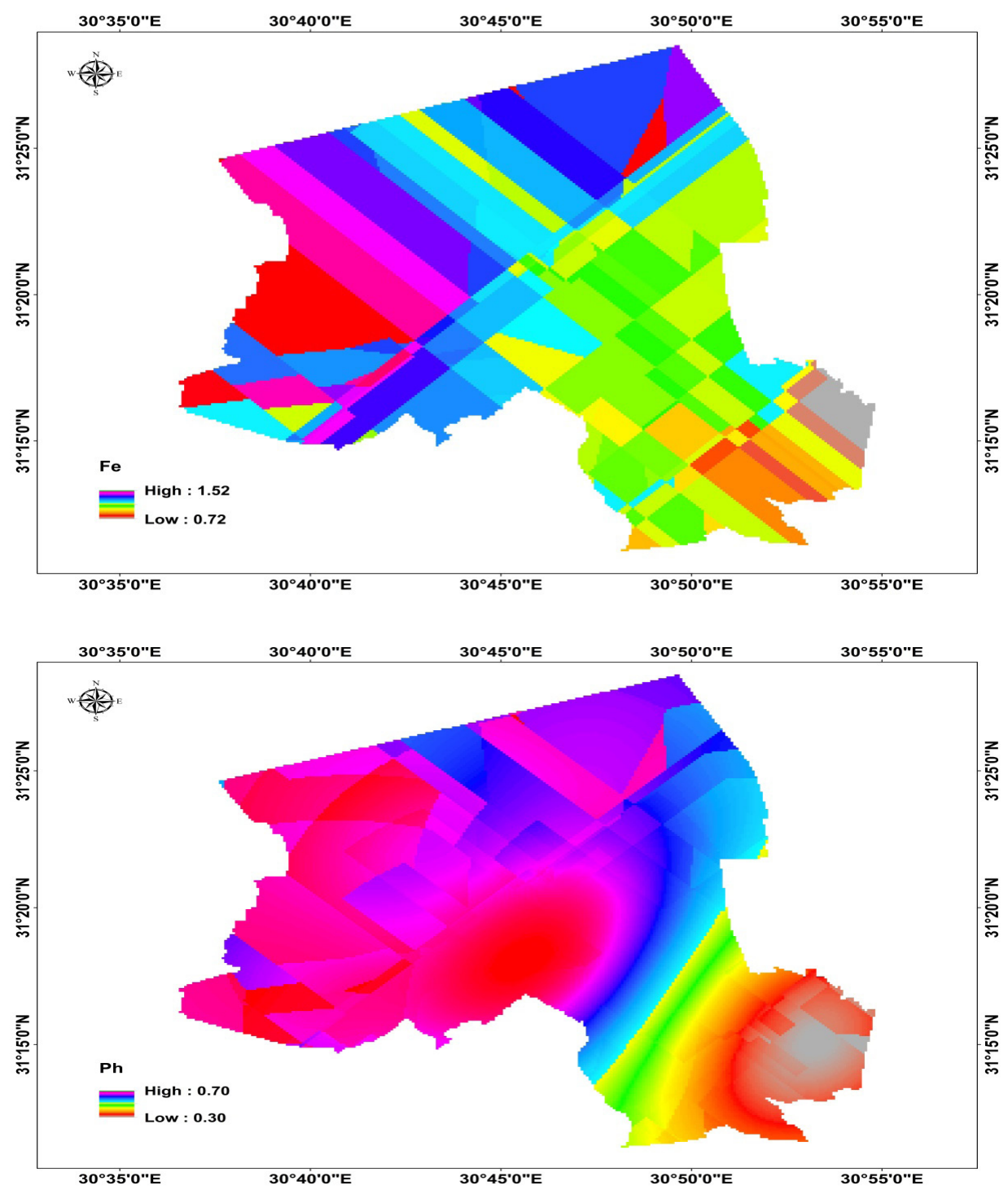

Fig. 3. Some available heavy metals in the drainage water samples.

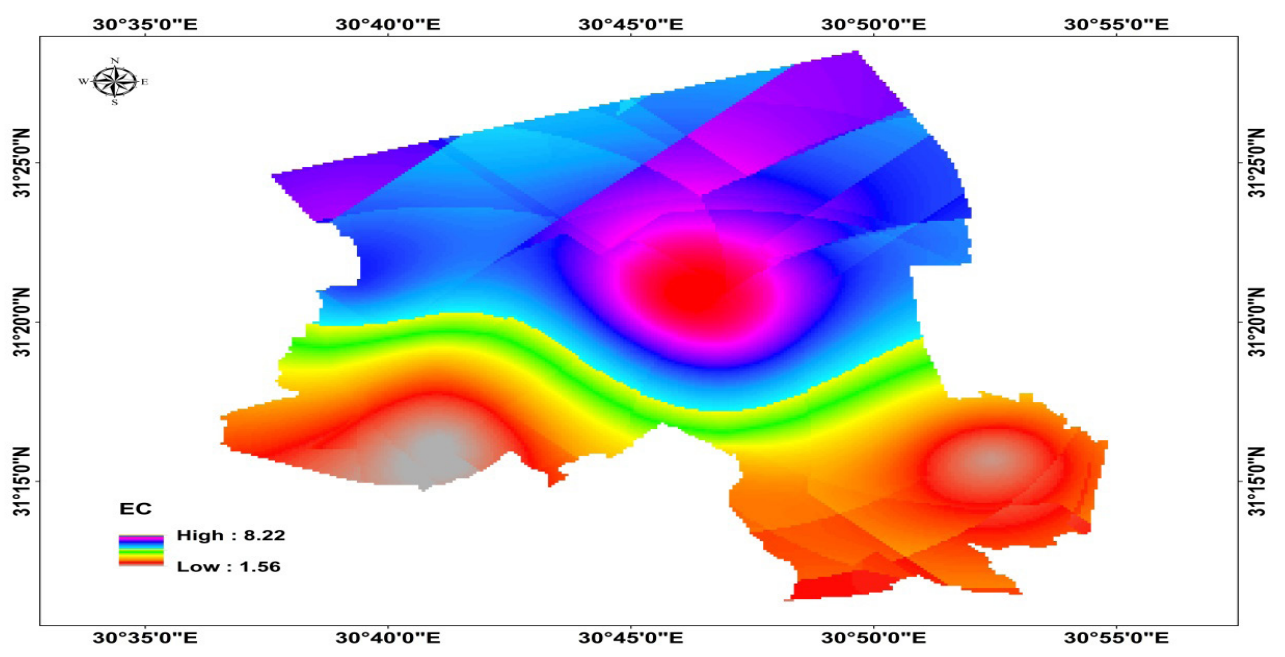

Fig. 4. The values of EC for the soil samples.

Env. Biodiv. Soil Security Vol. 3 (2019) 
$\mathrm{N}$-fertilizers for vegetable production. The mean values of $\mathrm{N}$ in soil were decreased towards the ends of drains and water canals (111 to $29.5 \mathrm{ppm}$ in the first line), may be due to the increase of salinity level.

\section{Heavy metals in soil}

Data in Table (3) showed clearly that the heavy metals content of the studied soil were parallel to the contents of heavy metals in the drainage water. Heavy metals contents ( $\mathrm{Mn}, \mathrm{Pb}, \mathrm{Cd}, \mathrm{Fe}$ and $\mathrm{Zn}$ ) of the studied soil varied from one metal to another, and also from one drain to another. The data showed that the content of $\mathrm{Mn}, \mathrm{Pb}, \mathrm{Cd}, \mathrm{Fe}$ and $\mathrm{Zn}$ for all soil samples ranged from 0.0 to 6.3 , 0.01 to $1.31,0.0$ to $1.15,0.01$ to 11.0 and 0.0 to $4.30 \mathrm{mgL}^{-1}$, respectively.

Sea water intrusion into fresh water aquifers
The data in Fig. (6) showed the interfacing and monitoring of seawater. Locating the saline/fresh water and its dynamics are essential for sustainable management of coastal groundwater systems. Sea water intrusion is the movement of sea water into fresh water aquifers due to natural processes of human activities. $\mathrm{Cl} /\left(\mathrm{CO}_{3}^{-2}+\mathrm{HCO}_{3}\right)$ ratio, may also helpful in diagnosing sea water intrusion problems. The EC values of ground water were increased towards Burullus Lake and the sea. It could be rendered to the effect of artesian pressure of saline ground water near the sea, where the highest value reached $20.25 \mathrm{dS} / \mathrm{m}$ in the line 1 and the lowest value $2 \mathrm{dS} / \mathrm{m}$ was observed in the line 3 . Sea water intrusion were calculated for the studied groundwater samples and followed thedesending order of: line $3>$ line $2>$ line 1 . The problem of sea water intrusion is depending on the state of equilibrium between miscible fluids, fresh

TABLE 3. The mean values of the studied soils properties.

\begin{tabular}{|c|c|c|c|c|c|c|c|c|c|c|}
\hline & \multirow[b]{2}{*}{ Site } & \multirow{2}{*}{$\begin{array}{c}E C \\
d S / m\end{array}$} & \multirow{2}{*}{ SAR } & \multirow{2}{*}{ pH } & \multirow{2}{*}{$\begin{array}{l}\mathrm{NO}_{3} \\
\mathrm{mgl}^{-1}\end{array}$} & \multicolumn{5}{|c|}{ Available heavy metals $\left(\mathrm{mgl}^{-1}\right)$} \\
\hline & & & & & & Mn & $\mathbf{P b}$ & Cd & $\mathrm{Fe}$ & $\mathbf{Z n}$ \\
\hline \multirow{7}{*}{$\vec{\Xi}$} & L1 S1 & 0.85 & 2.68 & 7.22 & 111 & $\mathrm{Nd}$ & 0.01 & $\mathrm{Nd}$ & 0.016 & 0.2 \\
\hline & L1 S2 & 1.0 & 4.20 & 7.15 & 190 & 0.1 & 0.5 & 0.01 & $\mathrm{Nd}$ & 0.25 \\
\hline & L1 S3 & 2.2 & 3.66 & 8.02 & 92.5 & 1.1 & 1.5 & 1.9 & $\mathrm{Nd}$ & 0.31 \\
\hline & L1 S4 & 4.5 & 5.66 & 7.93 & 104 & 5.3 & 2.1 & 3.5 & $\mathrm{Nd}$ & 0.5 \\
\hline & L1 S5 & 6.1 & 8.78 & 8.32 & 29.5 & 6.3 & 1.58 & 2.5 & $\mathrm{Nd}$ & 0.55 \\
\hline & Average & 2.93 & 5.0 & 7.73 & 105.4 & 3.2 & 1.14 & 1.98 & 0.02 & 0.36 \\
\hline & SD & 2.3 & 2.37 & 0.52 & 57.27 & 3.01 & 0.86 & 1.55 & 0.01 & 0.15 \\
\hline \multirow{7}{*}{$\stackrel{\sim}{\mathscr{\Xi}}$} & L2 S1 & 1.8 & 3.03 & 7.75 & 40 & 2.15 & 0.89 & 1.18 & 0.01 & 0.25 \\
\hline & L2 S2 & 2.6 & 2.98 & 7.78 & 22.6 & 4.5 & 3.1 & 2.95 & 0.09 & 0.35 \\
\hline & L2 S3 & 5.5 & 9.56 & 8.45 & 32 & 4.37 & 8.5 & 1.45 & 0.51 & 0.4 \\
\hline & L2 S4 & 7.5 & 10.64 & 8.04 & 43 & 5.3 & 9 & 4.3 & 0.75 & 0.65 \\
\hline & L2 S5 & 8.73 & 12.11 & 8.41 & 45.0 & 10 & 11 & 3.5 & 1.15 & 1.1 \\
\hline & Average & 5.23 & 7.66 & 8.09 & 36.52 & 5.26 & 6.50 & 2.68 & 0.5 & 0.55 \\
\hline & SD & 3.01 & 4.35 & 0.33 & 9.22 & 2.89 & 4.29 & 1.34 & 0.47 & 0.34 \\
\hline \multirow{7}{*}{ 号 } & L3 S1 & 1.25 & 3.04 & 7.70 & 130 & 0.1 & 0.01 & $\mathrm{Nd}$ & $\mathrm{Nd}$ & 0.01 \\
\hline & L3 S2 & 2.84 & 2.84 & 7.95 & 80 & 0.2 & 0.2 & $\mathrm{Nd}$ & $\mathrm{Nd}$ & 0.1 \\
\hline & L3 S3 & 2.9 & 2.9 & 8.00 & 108 & 1.5 & 1.5 & 0.02 & 0.017 & 1.31 \\
\hline & L3 S4 & 5.3 & 5.3 & 8.10 & 110 & 2.7 & 1.7 & 0.06 & 0.024 & 1.06 \\
\hline & S3 S5 & 7.0 & 7.0 & 8.38 & 115 & 3.5 & 2.5 & 1.5 & 0.014 & 1.16 \\
\hline & Average & 3.86 & 4.22 & 8.03 & 108.6 & 1.6 & 1.18 & .53 & 0.02 & 0.73 \\
\hline & SD & 2.28 & 1.87 & 0.25 & 18.16 & 1.5 & 105 & 0.66 & 0.01 & 0.62 \\
\hline
\end{tabular}

$\mathrm{Nd}$ : not detected, SD : standerd deviation. 


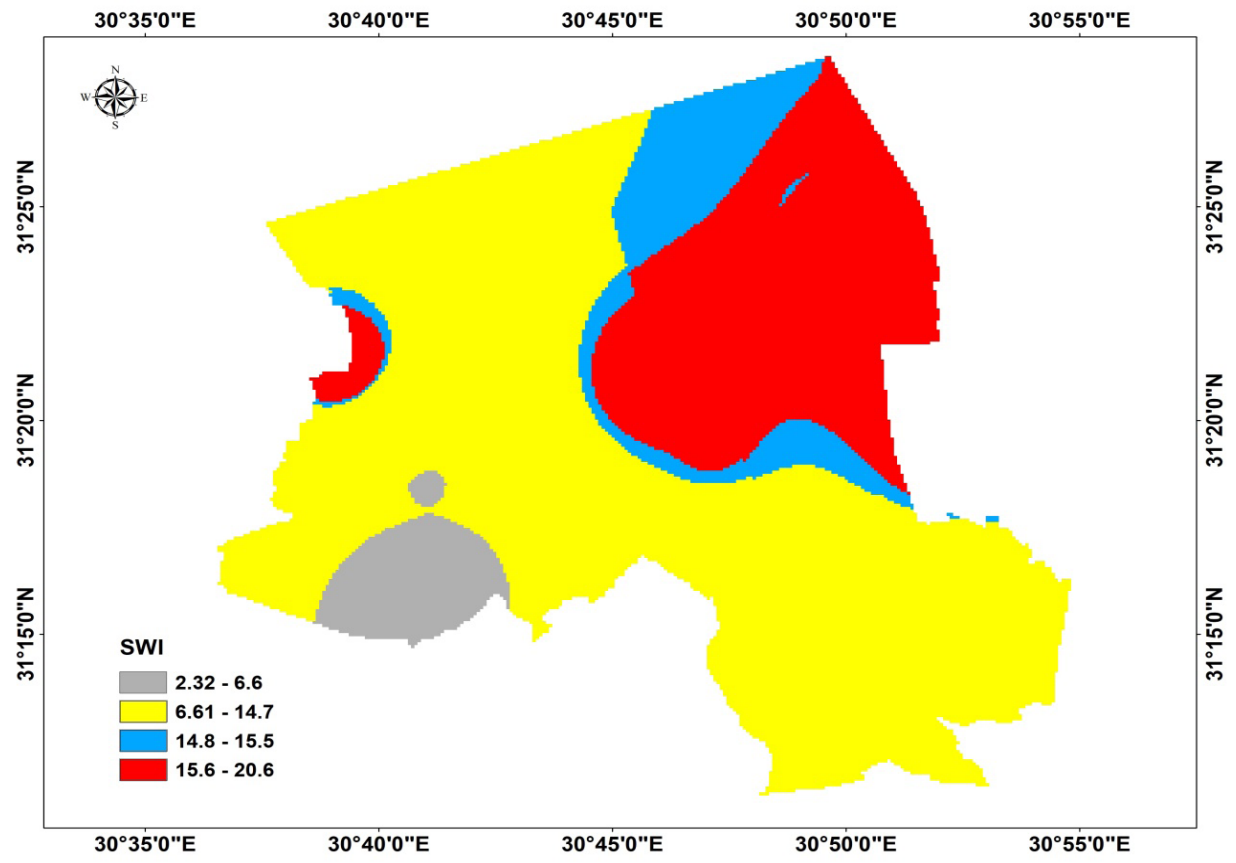

Fig. 5. Sea water intrusion in the ground water in the northern region.

groundwater and sea water. The contact zone is found between the lighter fresh water underlying sea water, which is actually considered as a mixing or transition zone through dispersion of water salinity (El-Ghannam 2012).

Assessement of water sources in the North Nile Delta by IWA-Model

- $\quad$ Salinity problems

Classification of irrigation, drainage and ground water with respect to salinity hazard is based primarily on the anticipated possible development of salinity in soil that will be irrigated with such water to the extent that yields are adversely affected. The EC values of the different water sources were increased towards the sea, and the average of EC values for irrigation and drainage wate were 1.2, 1.95, and $2.7 \mathrm{dS} / \mathrm{m}$. (Tables 4, 5 and 6). These values lie in the moderate category of salinity and their classification categories according to the USSL (1954) is $\mathrm{C}_{3}$ class with moderate limitation for use and needs leaching requirments at moderate rate. In general, it can be concluded that salinity of drainage water is slightly higher at line 3 than line 1.

\section{- $\quad$ Sodicity problems}

Although plant growth is primarily limited with the salinity of the irrigation water, the application of water with a sodium imbalance can further reduce yield under certain soil texture conditions. Reductions in water infiltration can occur when irrigation water contains high sodium relative to the calcium and magnesium contents. On the other hand, when quantities of residual sodium carbonate (RSC) were appreciable high $(-1.51,-7.99$ and -34.1 for irrigation, drainage and groundwater, respectively) as shown in Tables 4, 5 and 6, they can have an appreciable sodicity hazard. The concept of RSC appears to relate better to sodicity problem in the field (FAO 1988).

- Permeability hazards

The soil permeability is affected by long term use of irrigation water as it influenced the sodium, calcium, magnesium and bicarbonate content of the soil. Doneen (1964) gave a criterion for assessing the suitability of groundwater for irrigation based on the permeability index which to claasified class1 $(>75 \%)$, class $2(25-75 \%)$ and class $3(<25 \%)$. Class 1 and 2 water are categorized as good for irrigation with $75 \%$ or more of maximum permeability. Class 3 water is unsuitable with $25 \%$ of maximum permeability as shown in Tables 4, 5 and 6 .

\section{Conclusion}

Using low quality water for irrigation purpose should be under control, with integrated soil management to avoid soil deterioration and reduction of yield production. all drains in the northern part flow back to the canals and many 
irrigation canals are contaminated with pollutants from domestic sources and heavy metals. So drainage water should be remidated to alleviate the amounts of heavy metals to the permissible limits. Cultivation of rice crop is a must in the coastal area to avoid sea water intrusion.

TABLE 4. Quality assessement of irrigation water by IWA-model.

\begin{tabular}{|c|c|c|c|c|c|c|c|c|c|c|c|c|}
\hline \multirow{2}{*}{ Ð્ઇ } & $\mathrm{S} 2$ & 49.93 & 2.68 & -0.40 & 2.47 & 75.83 & 3.01 & 41.18 & $\mathrm{C} 2$ & $\mathrm{~S} 1$ & $\mathrm{C} 2 \mathrm{~S} 1$ & Good \\
\hline & $\mathrm{S} 3$ & 51.98 & 3.33 & -1.00 & 2.89 & 72.32 & 4.16 & 33.33 & $\mathrm{C} 3$ & $\mathrm{~S} 1$ & C3S1 & Appropriate \\
\hline \multirow{4}{*}{ 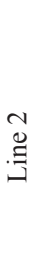 } & $\mathrm{S} 1$ & 38.46 & 1.82 & -0.60 & 1.79 & 66.73 & 2.33 & 48.78 & $\mathrm{C} 2$ & $\mathrm{~S} 1$ & $\mathrm{C} 2 \mathrm{~S} 1$ & Good \\
\hline & $\mathrm{S} 2$ & 33.16 & 1.60 & -0.55 & 1.51 & 61.46 & 2.60 & 43.56 & $\mathrm{C} 2$ & $\mathrm{~S} 1$ & $\mathrm{C} 2 \mathrm{~S} 1$ & Good \\
\hline & S3 & 36.48 & 1.84 & 0.55 & 1.61 & 66.82 & 1.83 & 34.34 & $\mathrm{C} 2$ & $\mathrm{~S} 1$ & $\mathrm{C} 2 \mathrm{~S} 1$ & Good \\
\hline & $\mathrm{S} 4$ & 41.61 & 2.14 & -0.70 & 1.89 & 68.09 & 2.88 & 35.71 & $\mathrm{C} 3$ & $\mathrm{~S} 1$ & $\mathrm{C} 3 \mathrm{~S} 1$ & Appropriate \\
\hline \multirow{4}{*}{$\stackrel{m}{\mathscr{0}}$} & $\mathrm{S} 2$ & 53.92 & 3.53 & -1.75 & 3.35 & 71.00 & 6.04 & 44.44 & $\mathrm{C} 3$ & $\mathrm{~S} 1$ & C3S1 & Appropriate \\
\hline & $\mathrm{S} 3$ & 48.58 & 3.42 & -2.15 & 3.14 & 65.84 & 6.58 & 40.65 & $\mathrm{C} 3$ & $\mathrm{~S} 1$ & $\mathrm{C} 3 \mathrm{~S} 1$ & Appropriate \\
\hline & $\mathrm{S} 4$ & 50.12 & 3.66 & -0.95 & 3.61 & 69.10 & 6.31 & 48.39 & $\mathrm{C} 3$ & $\mathrm{~S} 1$ & C3S1 & Appropriate \\
\hline & S5 & 46.67 & 3.57 & -0.75 & 3.59 & 65.55 & 7.25 & 50.65 & $\mathrm{C} 3$ & $\mathrm{~S} 1$ & C3S1 & Appropriate \\
\hline \multicolumn{2}{|c|}{ Average } & 48.09 & 3.65 & -1.51 & 1.20 & 3.56 & 68.98 & 43.15 & & & & \\
\hline \multicolumn{2}{|c|}{ SD } & 9.64 & 2.61 & 2.23 & 1.14 & 2.92 & 5.32 & 7.37 & & & & \\
\hline
\end{tabular}

*SSP soluble sodium percentage, SAR sodium adsorption ratio, RSC residual sodium carbonate, SCAR sodium calicm activity ration, PI permeability index, PS potinal salinity, MAR maginsem hazard, ST standard deviation.

[I] [IWA-Mod Ver. 1.0-2013] - Irrigation Water Assessment Model

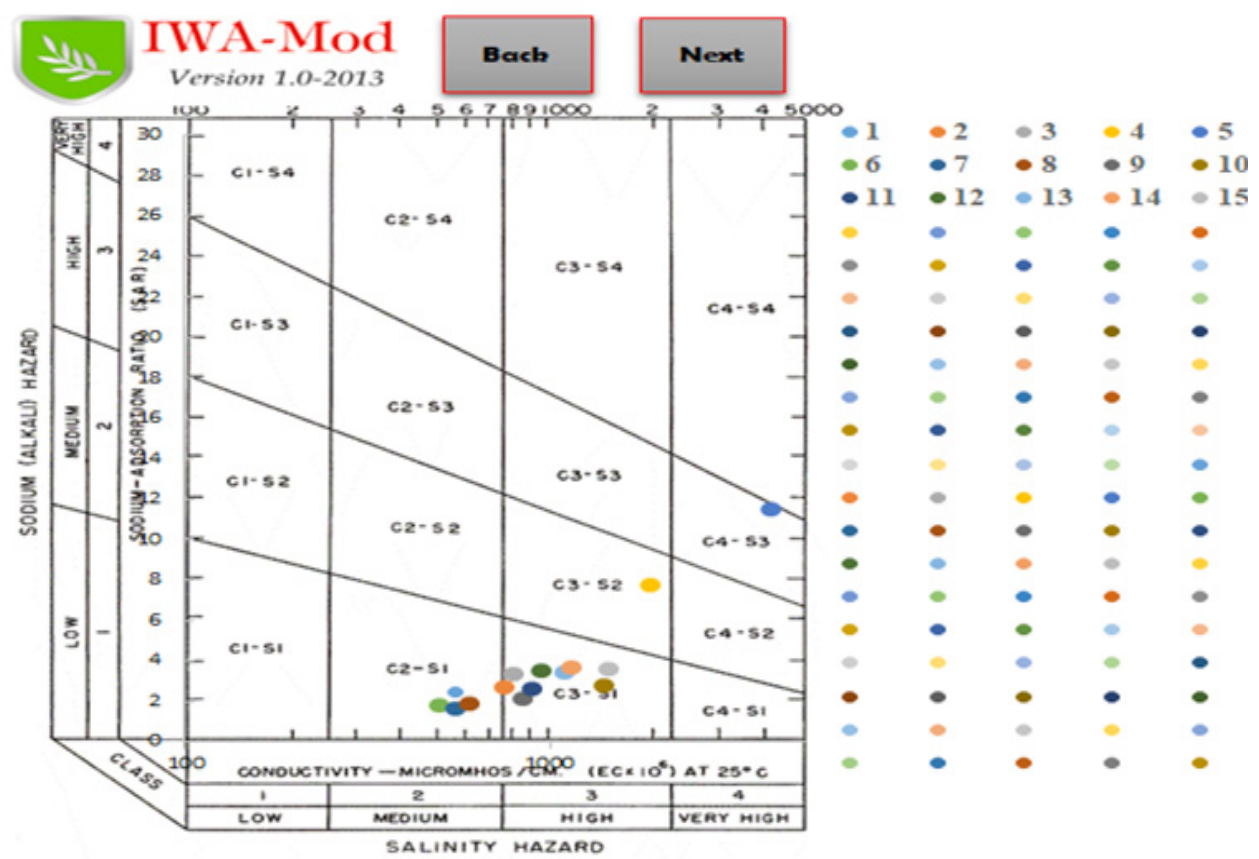

Fig. 6. Classification of irrigation water on the digram of USDA (1954).

Env. Biodiv. Soil Security Vol. 3 (2019) 
TABLE 5. Quality assessement of drainage water.

\begin{tabular}{|c|c|c|c|c|c|c|c|c|c|c|c|c|}
\hline \multicolumn{2}{|c|}{ Location } & SSP & SAR & RSC & SCAR & PI & PS & MAR & $\begin{array}{l}\text { Salinity } \\
\text { Hazard }\end{array}$ & $\begin{array}{l}\text { Sodicity } \\
\text { Hazard }\end{array}$ & $\begin{array}{l}\text { USSL } \\
\text { Index }\end{array}$ & $\begin{array}{l}\text { USSL } \\
\text { Class }\end{array}$ \\
\hline \multirow{5}{*}{ 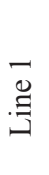 } & S1 & 25.64 & 2.06 & -11.30 & 2.63 & 36.47 & 12.85 & 69.41 & $\mathrm{C} 3$ & S1 & C3S1 & Appropriate \\
\hline & S2 & 40.78 & 3.44 & -5.40 & 3.68 & 53.94 & 5.90 & 56.30 & $\mathrm{C} 3$ & S1 & C3S1 & Appropriate \\
\hline & S3 & 43.92 & 3.27 & -3.90 & 3.17 & 59.03 & 7.85 & 46.84 & $\mathrm{C} 3$ & S1 & $\mathrm{C} 3 \mathrm{~S} 1$ & Appropriate \\
\hline & S4 & 60.86 & 9.54 & -12.00 & 9.17 & 66.42 & 39.33 & 45.95 & $\mathrm{C} 4$ & S3 & $\mathrm{C} 4 \mathrm{~S} 3$ & Very poor \\
\hline & S5 & 58.56 & 8.45 & -10.50 & 9.13 & 65.05 & 31.85 & 57.14 & $\mathrm{C} 4$ & S3 & $\mathrm{C} 4 \mathrm{~S} 3$ & Very poor \\
\hline \multirow{5}{*}{$\begin{array}{l}\stackrel{\sim}{\Xi} \\
\stackrel{\Xi}{\Xi}\end{array}$} & S1 & 51.16 & 4.94 & -2.90 & 4.42 & 65.29 & 11.75 & 37.37 & $\mathrm{C} 3$ & S2 & $\mathrm{C} 3 \mathrm{~S} 2$ & Acceptable \\
\hline & S2 & 47.90 & 3.95 & -1.50 & 3.95 & 65.36 & 8.50 & 50.00 & $\mathrm{C} 3$ & S1 & C3S1 & Appropriate \\
\hline & S3 & 42.76 & 3.15 & 1.50 & 3.25 & 64.42 & 4.85 & 52.94 & $\mathrm{C} 3$ & S1 & C3S1 & Appropriate \\
\hline & S4 & 40.98 & 3.78 & -8.00 & 5.35 & 51.87 & 14.70 & 75.00 & $\mathrm{C} 3$ & S1 & $\mathrm{C} 3 \mathrm{~S} 1$ & Appropriate \\
\hline & S5 & 49.50 & 4.96 & 0.20 & 5.20 & 64.37 & 11.68 & 54.47 & $\mathrm{C} 4$ & S2 & $\mathrm{C} 4 \mathrm{~S} 2$ & poor \\
\hline \multirow{5}{*}{$\stackrel{\Re}{\stackrel{\Xi}{\Xi}}$} & S1 & 55.84 & 7.55 & -10.70 & 6.10 & 62.85 & 29.50 & 23.53 & $\mathrm{C} 3$ & S2 & $\mathrm{C} 3 \mathrm{~S} 2$ & Acceptable \\
\hline & S2 & 62.95 & 6.76 & 0.60 & 6.58 & 77.59 & 10.23 & 47.30 & $\mathrm{C} 3$ & S2 & $\mathrm{C} 3 \mathrm{~S} 2$ & Acceptable \\
\hline & S3 & 54.38 & 10.52 & -28.10 & 11.47 & 58.62 & 54.60 & 57.95 & $\mathrm{C} 3$ & S3 & $\mathrm{C} 3 \mathrm{~S} 3$ & Acceptable \\
\hline & S4 & 41.60 & 5.42 & -20.30 & 6.24 & 47.71 & 32.75 & 62.28 & $\mathrm{C} 4$ & S2 & $\mathrm{C} 4 \mathrm{~S} 2$ & poor \\
\hline & S5 & 49.34 & 5.48 & -7.50 & 6.71 & 59.13 & 16.95 & 66.67 & $\mathrm{C} 4$ & S2 & $\mathrm{C} 4 \mathrm{~S} 2$ & poor \\
\hline \multirow{2}{*}{\multicolumn{2}{|c|}{$\begin{array}{l}\text { Average } \\
\text { SD }\end{array}$}} & 48.41 & 5.55 & -7.99 & 5.80 & 59.87 & 19.55 & 53.54 & & & & \\
\hline & & 9.64 & 2.51 & 8.10 & 2.54 & 9.60 & 14.61 & 12.87 & & & & \\
\hline
\end{tabular}

[X] [IWA-Mod Ver. 1.0-2013] - Irrigation Water Assessment Model

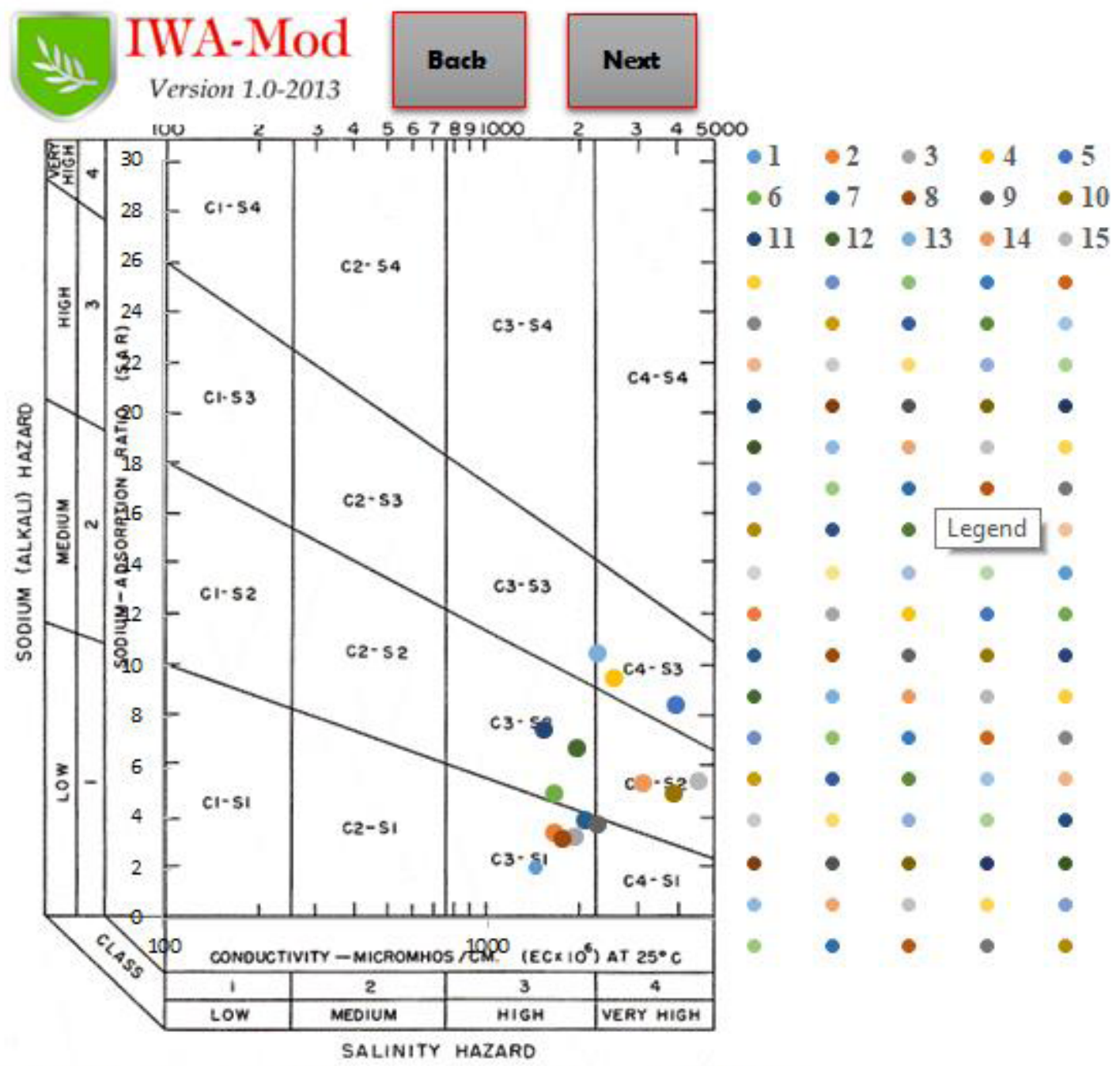

Fig. 7. Classification of drainage water on the digram of USDA (1954).

Env. Biodiv. Soil Security Vol. 3 (2019) 
TABLE 6. Quailty assessement of ground water.

\begin{tabular}{|c|c|c|c|c|c|c|c|c|c|c|c|c|}
\hline \multicolumn{2}{|c|}{ Location } & SSP & SAR & RSC & SCAR & PI & PS & MAR & $\begin{array}{l}\text { Salinity } \\
\text { Hazard }\end{array}$ & $\begin{array}{c}\text { Sodicity } \\
\text { Hazard }\end{array}$ & $\begin{array}{l}\text { USSL } \\
\text { Index }\end{array}$ & $\begin{array}{l}\text { USSL } \\
\text { Class }\end{array}$ \\
\hline \multirow{4}{*}{ 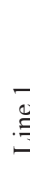 } & S1 & 64.02 & 10.98 & -13.21 & 10.11 & 69.36 & 38.33 & 41.04 & $\mathrm{C} 4$ & S4 & C4S4 & Very poor \\
\hline & S2 & 62.48 & 12.58 & -22.64 & 11.19 & 66.10 & 55.50 & 36.78 & $\mathrm{C} 4$ & S4 & C4S4 & Very poor \\
\hline & S3 & 55.91 & 11.10 & -30.54 & 10.63 & 59.59 & 60.48 & 45.46 & $\mathrm{C} 4$ & S4 & C4S4 & Very poor \\
\hline & S4 & 61.37 & 16.03 & -43.99 & 14.93 & 63.64 & 100.64 & 42.41 & $\mathrm{C} 4$ & $\mathrm{~S} 4$ & C4S4 & Very poor \\
\hline \multirow{6}{*}{ 光 } & S5 & 64.05 & 18.38 & -46.37 & 16.77 & 66.08 & 109.82 & 39.97 & $\mathrm{C} 4$ & S4 & C4S4 & Very poor \\
\hline & S1 & 58.73 & 9.60 & -15.84 & 8.52 & 64.37 & 38.06 & 36.53 & $\mathrm{C} 4$ & S3 & $\mathrm{C} 4 \mathrm{~S} 3$ & Very poor \\
\hline & S2 & 60.47 & 12.89 & -27.57 & 11.81 & 64.21 & 64.50 & 40.45 & $\mathrm{C} 4$ & S4 & $\mathrm{C} 4 \mathrm{~S} 4$ & Very poor \\
\hline & S3 & 60.66 & 13.33 & -28.85 & 12.38 & 64.34 & 67.94 & 42.06 & $\mathrm{C} 4$ & S4 & C4S4 & Very poor \\
\hline & S4 & 61.99 & 17.03 & -46.55 & 15.14 & 64.29 & 105.56 & 36.79 & $\mathrm{C} 4$ & S4 & C4S4 & Very poor \\
\hline & S5 & 64.88 & 19.62 & -47.92 & 17.59 & 67.03 & 126.46 & 37.78 & $\mathrm{C} 4$ & S4 & $\mathrm{C} 4 \mathrm{~S} 4$ & Very poor \\
\hline \multirow{5}{*}{ 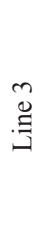 } & S1 & 55.56 & 9.88 & -15.60 & 9.62 & 61.75 & 43.45 & 47.30 & $\mathrm{C} 4$ & S3 & $\mathrm{C} 4 \mathrm{~S} 3$ & Very poor \\
\hline & S2 & 60.52 & 11.43 & -9.50 & 11.22 & 66.93 & 47.40 & 48.15 & $\mathrm{C} 4$ & S4 & C4S4 & Very poor \\
\hline & S3 & 61.57 & 13.73 & -29.05 & 13.10 & 64.99 & 68.75 & 45.11 & $\mathrm{C} 4$ & S4 & $\mathrm{C} 4 \mathrm{~S} 4$ & Very poor \\
\hline & S4 & 54.00 & 16.57 & -77.00 & 14.67 & 56.35 & 171.90 & 36.22 & $\mathrm{C} 4$ & S4 & $\mathrm{C} 4 \mathrm{~S} 4$ & Very poor \\
\hline & S5 & 63.82 & 20.16 & -56.91 & 18.56 & 65.73 & 135.61 & 40.99 & $\mathrm{C} 4$ & S4 & C4S4 & Very poor \\
\hline \multicolumn{2}{|c|}{ Average } & 60.7 & 14.2 & 34.1 & 13.1 & 64.3 & 82.3 & 41.1 & & & & \\
\hline \multicolumn{2}{|c|}{ SD } & 3.3 & 3.5 & 18.7 & 3.1 & 3.2 & 40.5 & 4.0 & & & & \\
\hline
\end{tabular}

X] [IWA-Mod Ver. 1.0-2013] - Irrigation Water Assessment Model

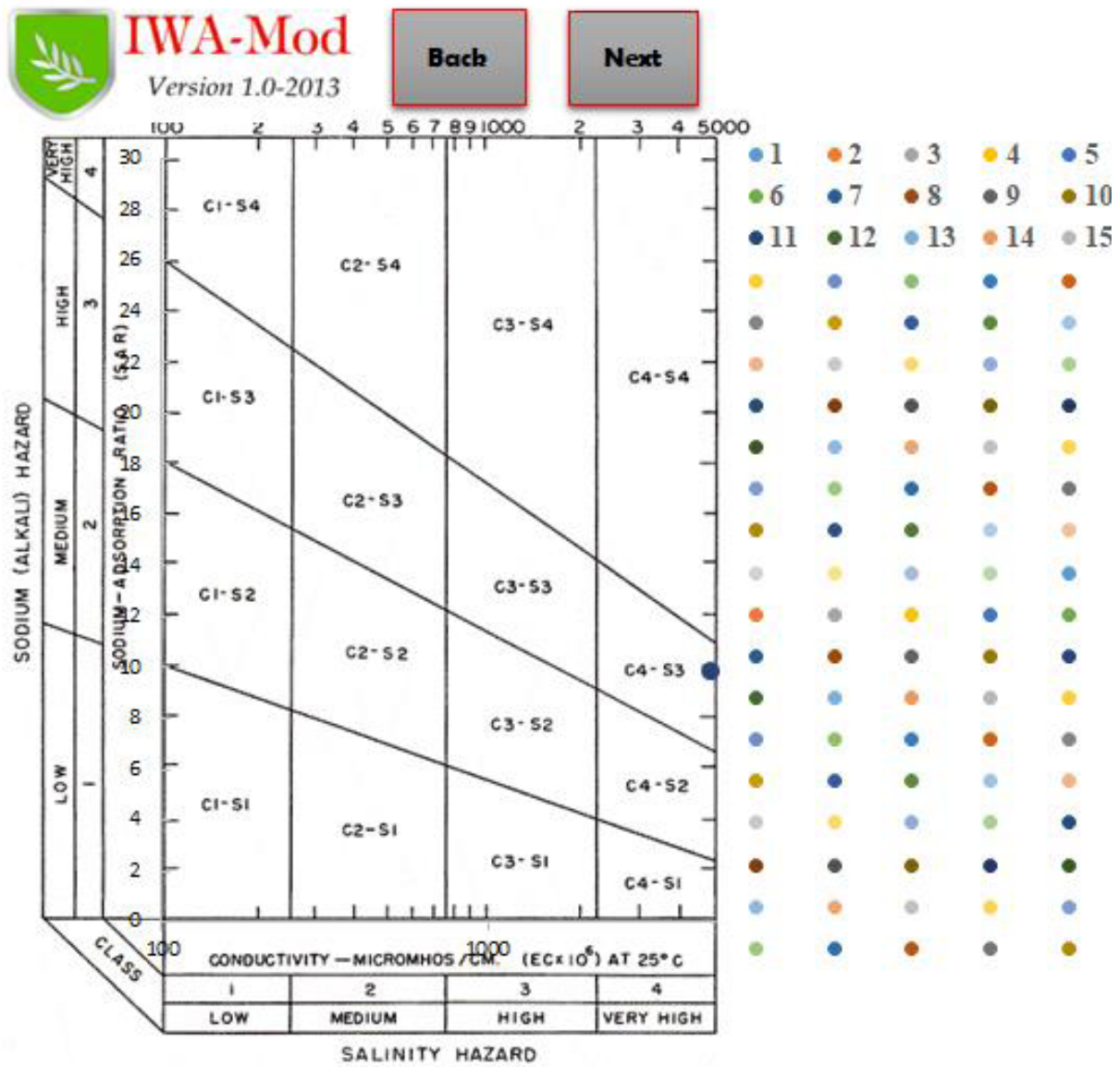

Fig. 8. Classification of groundwater on the digram of USDA (1954).

Env. Biodiv. Soil Security Vol. 3 (2019) 


\section{References}

Abdallah SA, HR El-Ramady, AE El-Sherbeni, HA Anber, EA Kishk, S Hamed, HM Amine (2019) Monitoring Water Quality of Some Canals in Delta Region, Egyp. Env. Biodiv. Soil Security 3, 73 - 95

Abdel-Razek, M.A.; A.M. Abozeid; M.M. Eltholth; F.A. Abouelenien; S.A. El-Midany; N.Y. Moustafa and R.A. Mohamed (2019) Bioremediation of a pesticide and selected heavy metals in wastewater from various sources using a consortium of microalgae and cyanobacteria. Slov Vet; 56 (Suppl 22): 61-73.

Afify D. G. Al-Afify; M. T. Usama; and H. A. Mohammed (2019) Water Quality Index and Microbial Assessment of Lake Qarun, El-Batts and El-Wadi Drains, Fayoum Province, Egypt Egyptian Journal of Aquatic Biology \& Fisheries. Ain Shams University, Cairo, Egypt. 23(1): 341 -357.

Allam, M.N. and G. I. Allam (2007) Water Resources in Egypt, Future Challenges and Opportunities. International Water Resources Association, 32, 205-218.

Antar, A. S., A.A. S. Gendy and G. M. A. El-Sanat (2012) Study on some agrochemical pollutants in drains water at North Delta, Egypt. J, of Soil Sciences and Agricultural Engineering.Mansoura Univ. 3 (2): 237-247.

Anwar, S.and Abdul Gaffar (2018) Patterns of Ground Water Pollutions along Charrar Drain in Lahore - Pakistan. Journal of the Punjab University Historical Society 31 (2), July - December.

Awad, S. R. (2019) Groundwater hydrogeology and quality in Helwan area and its vicinities in Egypt Water Science, 33 (1), 10-21.

Choudhary O.P and Kharche V.K. (2018) Soil Salinity and Sodicity. https://www.researchgate.net/ publication/327824188.

Cottenie, A.; Verloo, M.; Velghe, G and Kiekens, L. (1982) Biological and analytical aspects of soil pollution. Lap of analytical and Agric. State Univ, Chent, Belgium.

Dinnes, D.L.; Karten; D.B. Jaynes; T.C.Kasper; J.L.Hatfield; T.S. Colvin and C.A. Cambardella (2002) Nitrogen management strategies to reduce nitrate leaching in the tile drained Midwertern soils. Agronomy J. 94(1): 153-171.

Doneen, L.D. (1964). Notes on water quality in Agriculture. Water Science and Engineering paper
No.4001.Dept. of water Csii. And Eng., Calif. Univ., USA.

Eaton, A.D.; Clesceri, L.S.; Rice, E.W. and Greenberg, A.H. (2013) Standard Methods for The Examination of Water and Wastewater (22 ${ }^{\text {nd }}$ edit.). American Public Health Association, 1123p.

El-Ghannam, M (2012) Influence of water level fluctuation in the ends of drains and water canals on the properties of soils and ground water in the North Nile Delta. MSc. Thesis, Fac. Agric. KFS, Univ.

El-Kiki, M.H (2018) Effect of sea water intrusion on Nile Delta and possible suggested solution. https:// www.researchgate.net/publication/327833959

El-Sanafawy Hameda M.A.; Nour El-Din, M. and N. I. Talha (2010) Monitoring of some chemical and biological pollutants in wastewater drains of Middle Delta region. Egyptian Soil Science Society (ESSS) $9^{\text {th }}$ National Conference on Oct. 18-20, 2010, Cairo, P3-3.

ESRI (2012) Arc GIS Geostatistical Analyst Tutorial (ArcGIS ${ }^{\circledR} 10.1$ ). ESRI, USA.

FAO (2002) Agricultural drainage water management in arid and semi arid areas. FAO irrigation and drainage Paper 6, Natural resourses management and environment dept.

FAO/RNEA (1993) Considerations of wastewater reuse system for irrigation. Tech. Bull. No. 7, P. 18.

FAO (1988) Salt affected soils and their management, FAO soils bulletin 39, FAO, Rome, Italy.

Heba Elbasiouny; F. Elbehiry and M. Abowaly (2017) Soil Quality Indices- Special Focus on SaltAffected Soil: Review and Case Study in Northern Egypt. Env. Biodiv. Soil Security 1, 85- 100.

Ibrikci, H., Cetin, M., Karnez, E., Flügel, W.A., Tilkici, B., Bulbul, Y., and Ryan, J. (2015) Irrigationinduced nitrate losses assessed in a Mediterranean irrigation district. Agric. Water Manage. 148, 223 231.

Lindsay W. L and Norvell W.A (1978) Development of a DTPA Soil Test for Zinc, Iron, Manganese, and Copper. Soil. Sci. Soc. Am. J., 42,

MohanBabu APM, Viswanadh GK and Venkateswara Rao S (2013) Assessment of Saltwater Intrusion Along Coastal Areas of Nellore District, A.P. International Journal of Scientific \& Engineering Research 4 (7): 173-178. Retrieved from http:// 


\section{www.ijser.org.}

Petros P., A. Rogkala; P. P. Giannakopoulou; B. Tsikouras; P. Lampropoulou; S. Kalaitzidis; K. Hatzipanagiotou; N. Lambrakis and M. A. Christopoulou (2019) An Experimental Study for the Remediation of Industrial Waste Water Using a Combination of Low Cost Mineral Raw Materials. Minerals, 9, 207

Richards, L.A. (1954) Diagnosis and improvement of saline and alkaline soils. U.S. Dept. Agric., Handbook, No.60.

Rowell, D.L. (1994) Soil Science: Methods and Applications. Taylor and Francis Group, London and New York.
Shepl, Y.A., Y.H. Kotp, M.S. El-Deab, H.A. Shawky and B.E. Anadouli, (2017) Performance Enhancement of PA-TEFC RO Membrane by Using Magnesium Silicate Nano-particles. Journal of Inorganic and Organometallic Polymers and Materials, 27 (Suppl.1): 201.https://doi.org/10.1007/s10904-0170667-9.

U.S. Environmental Protection Agency (1991) National primary drinking water regulations, final rule. Fed. Regist. 56 (20): 3526-3594. 